\title{
Corticosteroids for critically ill COVID-19 patients with cytokine release syndrome: a limited case series
}

\author{
Stephen Su Yang, MDCM, FRCPC (D) Jed Lipes, MDCM, FRCPC
}

Received: 27 April 2020/Revised: 27 April 2020/Accepted: 29 April 2020/Published online: 11 May 2020

(C) Canadian Anesthesiologists' Society 2020

\section{To the Editor,}

Approximately 5\% of coronavirus disease (COVID-19) patients will require admission to an intensive care unit (ICU). ${ }^{1}$ Among these patients, the most severe cases may be mediated by a late-onset systemic inflammatory response with cytokine dysregulation referred to as cytokine release syndrome (CRS). ${ }^{2}$ Clinically, this results in fever, acute respiratory distress syndrome, multiorgan failure, and/or hemodynamic collapse due to distributive shock. Late-onset severe COVID-19 patients may respond to anti-inflammatory therapy without worsening the initial early viral infection. ${ }^{3}$ We describe a case series of 15 COVID-19 patients admitted to ICU who received corticosteroids in the context of CRS. Cytokine release syndrome was identified as worsening hypoxemia or vasoplegia with rising $\mathrm{C}$-reactive protein (CRP) or interleukin-6 levels without alternative clinical explanation. The Research Ethics Board at our local site approved this retrospective case series.

The characteristics of these patients are provided in the Table. The median [interquartile range (IQR)] age was 72 [62-74] yr (range, 45-75 yr), and nine of the 15 patients $(60 \%)$ were male. The indications for steroid

Electronic supplementary material The online version of this article (https://doi.org/10.1007/s12630-020-01700-w) contains supplementary material, which is available to authorized users.

S. S. Yang, MDCM, FRCPC ( $₫)$

Department of Anesthesia, Jewish General Hospital, Montreal,

QC, Canada

e-mail: stephen.yang@mail.mcgill.ca

J. Lipes, MDCM, FRCPC

Department of Internal Medicine, Jewish General Hospital,

Montreal, QC, Canada administration were hypoxic respiratory failure (67\%), vasoplegic shock on multiple vasopressors $(20 \%)$, or both respiratory and cardiovascular failure (20\%). Two nonintubated patients received steroids for impending respiratory failure with increasing inflammatory markers concerning for CRS. The median [IQR] day of steroid administration after symptoms onset was 14 [12-15] days. Nine patients $(60 \%)$ received methylprednisolone, four patients $(27 \%)$ received hydrocortisone, and two patients (13\%) received dexamethasone. The median [IQR] dose of corticosteroids during the first $24 \mathrm{hr}$ in methylprednisolone equivalents was 160 [83-160] mg. In almost all cases, there was a decrease in vasopressor requirement or an improvement in oxygenation after steroid administration. There was an average fall in CRP of $236 \mathrm{mg} \cdot \mathrm{L}^{-1}$ with steroid administration (eFig. 1, available as Electronic Supplementary Material [ESM]). An average increase in the arterial partial pressure of oxygen/fraction of inspired oxygen (i.e., P/F) ratio of 44 was detected $24 \mathrm{hr}$ after steroid administration (eFig. 2, available as ESM). Currently, four patients were discharged home, four patients remained in ICU, four patients were transferred to the medical ward, and three patients are deceased.

We present a subset of COVID-19 patients who presented with progressive respiratory failure along with progressive inflammatory biomarkers consistent with severe CRS. We found a significant clinical and biochemical association between corticosteroids and improved surrogate outcomes in late-onset CRS associated with COVID-19. Corticosteroids are indicated to treat CRS occurring from immune or chimeric antigen receptor therapy, but its use in weathering the cytokine storm in viral infection remains controversial, particularly if given early. ${ }^{4}$ Other coronaviruses have an inverted "V" distribution of viral shedding, peaking ten days after the 
Table Characteristics of 15 critically ill patients with COVID-19 who received corticosteroids

\begin{tabular}{|c|c|c|c|c|c|c|c|c|c|c|}
\hline No & $\begin{array}{l}\text { Age } \\
(\mathrm{yr})\end{array}$ & Sex & $\begin{array}{l}\text { Time from } \\
\text { symptoms to } \\
\text { steroids } \\
\text { (days) }\end{array}$ & $\begin{array}{l}\text { Steroid } \\
\text { administered }\end{array}$ & $\begin{array}{l}\text { Dosage of steroid over } \\
\text { first } 24 \mathrm{hr}- \\
\text { Methylprednisolone } \\
\text { equivalents }(\mathrm{mg})\end{array}$ & Indication & $\begin{array}{l}\text { Clinical change } \\
24 \mathrm{hr} \text { post } \\
\text { therapy }\end{array}$ & $\begin{array}{l}\mathrm{CRP} \\
\left(\mathrm{mg} \mathrm{L}^{-1}\right)\end{array}$ & $\begin{array}{l}\mathrm{P}_{\mathrm{a}} \mathrm{O} 2 / \\
\mathrm{F}_{\mathrm{I}} \mathrm{O} 2 \\
\text { ratio }\end{array}$ & $\begin{array}{l}\text { Current } \\
\text { condition }\end{array}$ \\
\hline 1 & 72 & M & 12 & Methylprednisolone & 160 & Vasoplegia & $\begin{array}{l}\text { Improved } \\
\text { hemodynamics }\end{array}$ & $348 \rightarrow 163$ & N/A & Ward \\
\hline 2 & 72 & M & 16 & Methylprednisolone & 160 & $\begin{array}{l}\text { Severe } \\
\text { ARDS }\end{array}$ & Moderate ARDS & $341 \rightarrow 9$ & $73 \rightarrow 130$ & ICU \\
\hline 3 & 62 & M & 10 & Hydrocortisone & 40 & $\begin{array}{l}\text { Severe } \\
\text { ARDS }\end{array}$ & Moderate ARDS & $455 \rightarrow 217$ & $77 \rightarrow 150$ & Ward \\
\hline 4 & 66 & M & 14 & Methylprednisolone & 160 & $\begin{array}{l}\text { Severe } \\
\text { ARDS }\end{array}$ & Severe ARDS & $378 \rightarrow 121$ & $71 \rightarrow 77$ & Deceased \\
\hline 5 & 53 & $\mathrm{~F}$ & 8 & Methylprednisolone & 160 & $\begin{array}{l}\text { Severe } \\
\text { ARDS }\end{array}$ & Moderate ARDS & $466 \rightarrow 150$ & $92 \rightarrow 100$ & ICU \\
\hline 6 & 63 & $\mathrm{~F}$ & 14 & Hydrocortisone & 60 & $\begin{array}{l}\text { Severe } \\
\text { ARDS \& } \\
\text { vasoplegia }\end{array}$ & $\begin{array}{c}\text { Moderate ARDS } \\
\text { and improved } \\
\text { hemodynamics }\end{array}$ & $556 \rightarrow 49$ & $83 \rightarrow 110$ & ICU \\
\hline 7 & 66 & M & 16 & Hydrocortisone & 60 & Vasoplegia & $\begin{array}{l}\text { Improved } \\
\text { hemodynamics }\end{array}$ & $293 \rightarrow 85$ & N/A & ICU \\
\hline 8 & 78 & M & 13 & Methylprednisolone & 160 & $\begin{array}{l}\text { Severe } \\
\text { ARDS \& } \\
\text { vasoplegia }\end{array}$ & $\begin{array}{c}\text { Moderate ARDS } \\
\text { and improved } \\
\text { hemodynamics }\end{array}$ & $425 \rightarrow 149$ & $60 \rightarrow 110$ & Deceased \\
\hline 9 & 55 & M & 14 & Dexamethasone & 106.7 & $5 \mathrm{~L} \mathrm{NP}$ & 1L NP & $210 \rightarrow 61$ & N/A & Home \\
\hline 10 & 74 & M & 13 & Dexamethasone & 106.7 & $5 \mathrm{~L} \mathrm{NP}$ & $4 \mathrm{~L} \mathrm{NP}$ & $297 \rightarrow 104$ & N/A & Home \\
\hline 11 & 72 & F & 14 & Methylprednisolone & 160 & $\begin{array}{l}\text { Severe } \\
\text { ARDS }\end{array}$ & Moderate ARDS & $115 \rightarrow 48$ & $87 \rightarrow 155$ & Home \\
\hline 12 & 75 & M & 12 & Hydrocortisone & 40 & Vasoplegia & $\begin{array}{l}\text { Improved } \\
\text { hemodynamics }\end{array}$ & N/A & N/A & Deceased \\
\hline 13 & 45 & $\mathrm{~F}$ & 12 & Methylprednisolone & 160 & $\begin{array}{l}\text { Severe } \\
\text { ARDS }\end{array}$ & Moderate ARDS & $80 \rightarrow 22$ & $82 \rightarrow 145$ & Home \\
\hline 14 & 75 & $\mathrm{~F}$ & 22 & Methylprednisolone & 120 & $\begin{array}{l}\text { Severe } \\
\text { ARDS }\end{array}$ & Severe ARDS & N/A & $81 \rightarrow 81$ & Ward \\
\hline 15 & 73 & $\mathrm{~F}$ & 17 & Methylprednisolone & 160 & $\begin{array}{l}\text { Severe } \\
\text { ARDS }\end{array}$ & Moderate ARDS & $368 \rightarrow 87$ & $94 \rightarrow 183$ & Ward \\
\hline
\end{tabular}

Severe ARDS defined as $\mathrm{PaO} 2 / \mathrm{F}_{\mathrm{I}} \mathrm{O} 2$ ratio $<100$, Moderate ARDS defined as $\mathrm{PaO}_{2} / \mathrm{F}_{\mathrm{I}} \mathrm{O}_{2}$ ratio $\geq 100$ and $<200$. ARDS $=$ acute respiratory distress syndrome; COVID-19 = coronavirus disease; $\mathrm{CRP}=\mathrm{C}$-reactive protein; $\mathrm{ICU}=$ intensive care unit; N/A = not available; $\mathrm{NP}=$ nasal prongs; $\mathrm{PaO}_{2} / \mathrm{F}_{\mathrm{I}} \mathrm{O}_{2}=$ arterial partial pressure of oxygen/fraction of inspired oxygen.

onset of symptoms and then decreasing rapidly. Consequently, the clinical deterioration occurring after ten days may be caused by dysregulated inflammation and not the virus itself, offering a window of opportunity for therapeutic intervention. ${ }^{4}$

Our report is limited by several important factors. There was no control group and therefore no randomization of intervention, we examined surrogate outcomes of uncertain clinical relevance, and there was likely selection bias in determining who received steroids and what dose they received. We report very few patients from a single centre, making it difficult to generalize our results to other hospitals even after consideration of the biases present. Additionally, exact criteria for CRS are not available and the prognostic importance of CRS in COVID-19 patients remains to be determined.

The fear of giving corticosteroids is related to a possible risk of decreased viral clearance with unclear clinical significance. ${ }^{5}$ Our report suggests the possibility of shortterm clinical improvements with corticosteroids and it highlights the need for urgent high-quality studies to determine whether steroid administration may meaningfully affect the outcomes of critically ill COVID19 patients.

Conflicts of interest None.

Funding statement None. 
Editorial responsibility This submission was handled by Dr. Philip M. Jones, Associate Editor, Canadian Journal of Anesthesia.

\section{References}

1. Wu Z, McGoogan JM. Characteristics of and important lessons from the coronavirus disease 2019 (COVID-19) outbreak in China: summary of a report of 72314 cases from the Chinese Center for Disease Control and Prevention. JAMA 2020; https://doi.org/10. 1001/jama.2020.2648.

2. Zhang $C$, Wu Z, Li JW, Zhao H, Wang GQ. The cytokine release syndrome (CRS) of severe COVID-19 and interleukin-6 receptor (IL-6R) antagonist tocilizumab may be the key to reduce the mortality. Int J Antimicrob Agents 2020;https://doi.org/10.1016/j. ijantimicag.2020.105954.

3. Lee N, Chan KC, Hui DS, et al. Effects of early corticosteroid treatment on plasma SARS-associated coronavirus RNA concentrations in adult patients. J Clin Virol 2004; 31: 304-9.

4. Gomersall $C D$. Pro/con clinical debate: steroids are a key component in the treatment of SARS. Pro: yes, steroids are a key component of the treatment regimen for SARS. Crit Care 2004; 8: 105-7.

5. Arabi YM, Mandourah Y, Al-Hameed F, et al. Corticosteroid therapy for critically ill patients with Middle East Respiratory Syndrome. Am J Respir Crit Care Med 2018; 197: 757-67.

Publisher's Note Springer Nature remains neutral with regard to jurisdictional claims in published maps and institutional affiliations. 